\title{
BUSINESS SERVICE INDUSTRIES - VENDORS OR OUTSOURCERS? EVIDENCE FROM POLAND
}

\begin{abstract}
ANNA GRZES
University of Bialystok, Faculty of Economics and Management, POLAND

e-mail: agrzes@uwb.edu.pl

RECEIVED

ACCEPTED

JEL

CLASSIFICATION

KEYWORDS

ABSTRACT

7 August 2017

15 December 2017

L24, L84, L89

business services, outsourcing, vendor, outsourcer, Poland

For the last decade dynamic growth of the business services sector has been observed in the Polish economy. In this sector net sales increases and more and more workers are employed. Among the main reasons of the growing demand for business services is the outsourcing of the auxiliary functions that were previously performed inside the enterprises and then outsourced to the companies providing the business services. The aim of this article was to recognize whether focusing on meeting the demand for the services business service industries also became outsourcers themselves. The analysis of this phenomenon was conducted on the basis of the unpublished aggregated data for the years 2005-2013, collected from the enterprises by the Central Statistical Office. This data confirmed that business service industries provided more services as vendors to outsourcers. However, they also concentrated on their core activity and outsourced many processes or tasks. All population of business service industries varied strongly.
\end{abstract}

\section{Introduction}

The service sector is the dominant sector in the Polish economy, as in the economies of many other countries. According to the data of the Central Statistical Office in the years 2005-2015 the share of this sector (without section 0 - public administration and national defence) amounted to 65-66\% (Wskaźniki, 2017) in creation of gross added value, and in the average employment rose from $62,2 \%$ in 2005 to $64,5 \%$ in 2013 and further to $64,7 \%$ 
in 2015 (Bank Danych, 2017). This sector involves social and business services. First of them meet the needs of customers and second ones are used as intermediate goods mainly in manufacturing processes. In Poland the most workers are employed in trade, repair, transport and construction, however, the employment rises continuously in the business services sector, in which there were 936 business services centres with 212,000 jobs in 2016 (Business services sector..., 2016).

Dynamic growth of the business services sector is partially a result of enterprises' answer to the important question: to make or to buy? Looking for ways to reduce costs and focusing on core competence, especially on production, firms made the decision to outsource some tasks or processes to firms specialising in providing such services cheaper and better. The increasing awareness of benefits of outsourcing has caused that more and more companies started to outsource and create demand for different business services, which has contributed to the development of the business services industry. In order to meet this demand and the expectations of their customers, business services industries had to become outsourcing vendors in a relatively short time. Additionally, as a result of offshoring, more and more Shared Services Centres and Business Process Outsourcing (SSC/BPO), which specialised in knowledge intensive, were located in Poland.

Growing competition in the business service market and increasing expectations of clients caused that business service enterprises had to redefine their business models to reduce the costs and to improve operational efficiency. Therefore, analysing processes or tasks they had to consider the basic question: to make or to buy, or in other words: to do it themselves or to outsource? The measurement of outsourcing is difficult because of mismatching of current financial reporting and the lack of published data in the national statistics. Additionally, researchers often focused on the causes of using international outsourcing and its consequences for labour productivity, employment, innovations, competitiveness, etc. For example, some of them studied the employment effects of the international outsourcing of services to low-wage countries (Falk, Wolfmayr, 2008; Amiti, Wei, 2005).

The aim of this article is to recognize whether business service industries in Poland while being outsourcing vendors of services also became outsourcers. The analysis of this phenomenon was conducted on the basis of unpublished aggregated data from the years 2005-2013 coming from the Central Statistical Office. The data was collected from enterprises employing 10 and more workers.

\section{Literature review}

The development of the business services sector in Poland was influenced by such factors as: expanding globalization, increase in the tradability of services due to advances in the information and communication technology (ICT), ability to fragmentation of services and outsourcing defined as the contracting out of a business processes or operations to third-party providers regardless of location or capital ties. With ICT many types of operations or functions that are traditionally performed in-house can be outsourced to domestic or foreign providers. Outsourcing is not a new phenomenon; it was initiated by manufacturing firms that began to specialise in core processes creating value additions and contracting out noncore ones. This way the trade in intermediate goods (production components) and also in various services has spurred (Falk, Wolfmayer, 2008).

Increased demand for business services and expectations of outsources caused that enterprises, which existed in business services industry, also had to specialise in core competence and they became outsourcers themselves. In order to be competitive and to deliver services to outsourcers at the appropriate level they also had to invest in fixed assets, abandon some ineffective operations, and specialise in core services. 
The survey of almost 3,700 respondents (including 30\% of service providers) from eight European countries (Denmark, Finland, Germany, Netherland, Norway, Spain, Sweden, UK), conducted by Ernst and Young in 2013, showed that outsourcing of services was perceived as the next step to decreasing costs and then improving effectiveness. The organizations made services in-house more often (between 81-91\%), and outsourced about 9-17\%. The most favoured services were IT and business processes (sales, procurement and Human Resources, finance and accounting). There were differences between countries in service outsourcing (Outsourcing in Europe..., 2013). Outsourcing abroad was used more often by Finland and Spain. Deloitte survey in 2014 showed that outsourcers focused on optimizing vendor relationships and improving operational flexibility. Their behaviour suggests that vendors had to provide high quality services. In order to do this they developed their core competences and outsourced some services or goods abroad or to vendors in the origin country.

Business services outsourcing market in Poland is one of the leading markets in Europe and in the world. It has been growing continuously for the decade due to the location of foreign and domestic BPO/SSC centres. 10 out of 23 biggest centres in the world operate here, such as: IBM, Intel, Shell, Google, HP, Carlsberg, Procter \& Gamble, and others. Apart from the BPO/SSC centres, Polish smaller entities also operate on this market that support mainly domestic and also foreign outsourcers. It can be assumed that the enterprises which deal with business services are outsourcing vendors. This means that net sales of products can be used to identify the size of business services outsourcing market in Poland.

\section{How to megsure outsourcing?}

The review of literature revealed that outsourcing is defined ambiguously also as: offshoring, integration, fragmentation, international (or foreign) outsourcing (Feenstra, Hanson, 1999; Amiti, Wei, 2005; Lewine, 2012; OECD, 2007; Espino-Rodriguez, Padron-Robaina, 2006). In spite of the diversity, the essence of these terms lies in the separation outside the firm and acquiring some processes or tasks that are not performed internally.

The result of outsourcing are intermediate inputs (goods or services) that are used to prepare the final products. However, the phenomenon of outsourcing is difficult to quantify because of lack of explicit categories, which could define it clearly. Financial statements contain neither the information about the value of outsourcing contracts nor detailed data about intermediate inputs. The author is also aware that not all purchases of intermediate goods or services should be treated as outsourcing and the data coming from these statements make it impossible to determine the true value of one. For example, the available data also includes operations that are a one-time purchase of a component required to produce finished goods or a one-time subcontracting services, but it is not plausible to exclude them.

In order to determine the size of outsourcing intensity, especially of offshoring or international outsourcing intensity, researchers often used indirect, absolute, or relative measures such as the share of imported intermediate inputs in the total purchase of non-energy materials (Feenstra, Hanson, 1999), the share of imported intermediate inputs excluding energy by industry $i$ in the total intermediate inputs used by $i$ (Offshoring and employment..., 2007), the share of imported intermediate inputs including energy in total output (Geishecker, Görg, 2008) and the share of imported intermediate inputs including energy in value added (Hijzen, Görg, Hine, 2005). Growth in outsourcing is noticeable in the expansion of purchasing goods or services that are used as intermediate inputs. 


\section{Methodology of pesearch}

Business service industries provide services to other enterprises and so become the vendors of outsourcing. The volume of demand for their services is noticed in net sales of products in constant prices of the previous year.

These industries are also outsourcers. In order to measure the value of what they outsource, it was acknowledged that the size of outsourcing will be quantified by the value of intermediate inputs in constant prices of the previous year. Based on the financial statements, which enterprises had to submit to the Central Statistical Office in Poland, it was assumed that the direct material cost (without energy) means the value of material outsourcing and the outside services cost is the value of services outsourcing. The deflator CPI was used to calculate all data because of the lack of a suitable indicator for the business services. The study covered all business services industries in the period 2005-2013 according to the sections and divisions of Polish Classification of Activities - PKD 2007 (that is consistent with NACE Rev.2 codes - 2-digital level) included: publishing activities (J58); information technology activities (J62); other information service (data processing, hosting and related activities) (J63); legal and accounting activities (M69); management consultancy activities (M70.2); architectural and engineering activities, technical testing and analysis (M71); advertising and market research (M73); other professional, scientific and technical activities (M74); employment activities (N78); security and investigation activities (N80); cleaning activities (N81.2) and office administrative, office and other business support activities (N82) (Wskaźniki, 2017). In addition to these activities, real estate activities (L68) are included in business services (Obszary-tematyczne..., 2017). Due to the availability of data, the large diversity, and the limited size of the article, business services were divided into groups according to Eurostat indicators (Eurostat, 2017): knowledge - intensive services (KIBS) and less knowledge - intensive services (LKIBS). KIBS group consists of the sections: J58, J62-63, M69-71, M73-74, M78 and LKIBS group - sections: L68, N81-N82.

\section{Business services industries as outsourcing vendors in the period 2005-2013 in Poland}

In Polish economy in the last decade there has been a rapid growth of the business services sector. This is reflected in the increase in demand for these services (Figure 1) expressed in net sales with compound annual growth rate (CAGR) of $8.7 \%$ and in net sales of products with CAGR of $8.4 \%$ for the period $2005-2013$. Calculated

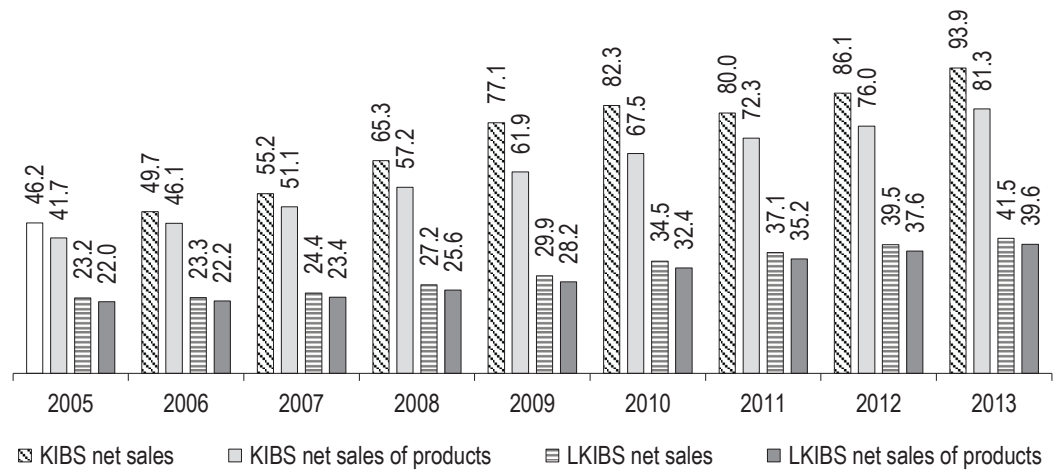

Figure 1. The volume of net sales and net sales of products in 2005-2013 (in billion zł, constant prices of previous year) Source: own calculations. 
CAGR of net sales for KIBS and LKIBS industries showed that net sales of the first group were higher (9.3\%) than of the second one (7.6\%). Similarly CAGR of net sales of products for KIBS industries was $8.7 \%$ and for LKIBS one was $7.6 \%$. This data confirms that the net sales of products that reflects outsourcing from vendors' side has been growing all the time in two groups: KIBS and LKIBS. Even the downturn in the Polish economy in 2009-2013 did not impede the demand for business services.

However, despite of small differences between them, in each of the two groups of industries-there were relatively large variations in these activities (Table 1). Large, over $15 \%$ annual growth rate was recorded in activities: N78, N82, J62-63 and M70. Enterprises that engaged in other professional, scientific and technical activities posted an annual decrease of $10.2 \%$.

Table 1. CAGR of net sales and net sales of products in business service industries between 2005 and 2013 (\%)

\begin{tabular}{lccccccccccccc}
\hline \multicolumn{1}{c}{ Item } & J58 & J62 & J63 & M69 & M70 & M71 & M73 & M74 & N78 & N80 & L68 & N81 & N82 \\
\hline Net sales & 1.9 & 14.5 & 21.7 & 17.3 & 21.8 & 6.4 & 3.5 & -11.1 & 29.3 & 8.0 & 6.0 & 4.8 & 26.4 \\
Net sales of products & 1.9 & 15.2 & 22.4 & 16.8 & 15.5 & 7.0 & 3.9 & -10.2 & 29.2 & 8.0 & 6.1 & 4.4 & 27.2 \\
\hline
\end{tabular}

Source: own calculations.

The analysis of the share of services' export in net sales of products has confirmed that more and more services were performed on behalf of foreign outsourcers (Figure 2).

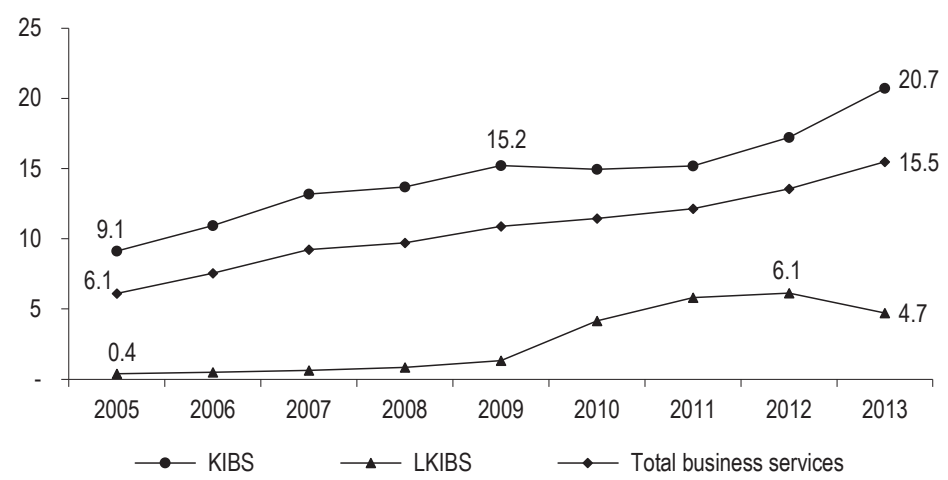

Figure 2. The share of services' export in net sales from products (\%) in KIBS, LKIBS and business service industries in 2005-2013

Source: own calculations.

The KIBS industries have been exporting more and more services year after year. The share of export in net sales from products of these industries to foreign outsourcers rose from $9.1 \%$ in 2005 to $20.7 \%$ in 2013 , while LKIBS rose from $0.4 \%$ in 2005 to $4.1 \%$ in 2013 . Since 2009 there has also been a noticeable increase in interest in less knowledge services. 


\section{Business services industries as outsourcers in the period 2005-2013 in Poland}

The increase in demand of business services, growing requirements of customers and competition between outsourcing vendors caused that they became aware of the need to concentrate on core competences and to use outsourcing in their activity in order to decrease operating costs and to meet demand of these services. For this reason they decided to outsource outside services and intermediate materials needed to produce and provide the services. Due to the specificity of business services, the dominant kind of outsourcing is service outsourcing, whose share in total outsourcing was at level of $67-85 \%$. The popularity of this phenomenon can be measured by CAGR for the period 2005-2013. In all sectors this index for total outsourcing was at $9.3 \%$, outsourcing services at $10.1 \%$, material outsourcing at $5.8 \%$. More difference in the growth rate occurred in both groups of business service. In KIBS group CAGR for total outsourcing shaped at level of $7.3 \%$, for service outsourcing at $9.3 \%$ and for material outsourcing at $1.2 \%$. For comparison, CAGR of both kinds of outsourcing was at level of $10.4-10.7 \%$. However, there was a relatively large variation in the value of this indicator in service activities (Table 2).

Table 2. CAGR of outsourcing and its kinds (in constant prices) in business service industries in the period 2005-2013 (\%)

\begin{tabular}{lrrrrrrrrrrrrr}
\hline \multicolumn{1}{c}{ Item } & J58 & J62 & J63 & M69 & M70 & M71 & M73 & M74 & N78 & N80 & L68 & N81 & N82 \\
\hline Total outsourcing & 0.4 & 15.9 & 24.7 & 18.1 & 20.9 & 9.8 & 4.6 & -10.7 & 31.9 & 11.0 & 7.3 & 9.2 & 28.7 \\
Service outsourcing & 1.6 & 18.3 & 27.2 & 18.4 & 22.0 & 12.0 & 6.0 & -10.9 & 34.8 & 13.6 & 6.0 & 7.5 & 32.1 \\
Material outsourcing & -1.4 & 8.1 & 4.1 & 12.0 & 8.9 & 6.6 & -5.5 & -9.6 & 19.1 & 3.6 & 7.7 & 10.4 & 24.4 \\
\hline
\end{tabular}

Source: own calculations.

Unpublished data collected by the Central Statistical Office confirmed that two kinds of outsourcing were used predominantly in activities such as: N78, N82. Enterprises from activities M70, J62, J63 used service outsourcing first of all due to their specific nature. The industries also included activities M74, M73, J58, which reordered a decrease of two kinds of outsourcing or only material outsourcing.

If we compare CAGR of outsourcing with CAGR of net sales of products, we can notice that the direction of these changes is similar. However, the growth rate of outsourcing is faster than the growth rate of net sales from products, which points at the increase of the popularity of outsourcing in production and delivery of services.

\section{Conclusions}

Outsourcing is a difficult phenomenon to measure due to lack of simple direct categories describing it. However, the choice of indirect ones allows to estimate its size, intensity, and annual growth rate.

The analysis of unpublished and collected data on net sales from products allowed to confirm that both groups: KIBS and LKIBS industries have increased continuously since 2005. This indicates that enterprises have provided more and more business services to outsourcers. Even the crisis of 2008 and downturn in the Polish economy in 2009-2013 did not impede the demand for business services. In order to meet the demand these industries outsourced more and more processes or tasks. But the growth rate of both, outsourcing and net sales, varied among the industries. These changes suggest that outsourcing has become a tool that has helped to reduce the employment growth or to escape the shortage of suitable employees, and also to maintain or to improve the 
effectiveness. Hence, it is necessary to conduct further research on the impact of outsourcing on the structure of employment.

\section{References}

Amiti, M., Wei, S.J. (2005). Fear of service outsourcing: is it justified? Economic Policy, 20 (42), 308-347.

Bank Danych (2017). Retrieved from: https://bdl.stat.gov.pl/BDL/metadane (15.06.2017).

Business services sector in Poland (2016). Retrieved from: http://absl.pl/wp-content/uploads/2016/09/Raport_ABSL_2016_EN.pdf (20.06.2017).

Espino-Rodriguez, T.F., Padron-Robaina, V. (2006). A review of outsourcing from the resource -based view of the firm. International Journal of Management Review, 1 (8), 49-70.

Eurostat (2017). Retrieved from: http://ec.europa.eu/eurostat/cache/metadata/Annexes/htec_esms_an3.pdf (4.11.2017).

Falk, M., Wolfmayr, Y. (2008). Services and materials outsourcing to low-wage countries and employment: Empirical evidence from EU countries. Structural Change and Economic Dynamics, 1 (19), 38-52.

Feenstra, R.C., Hanson, G.H. (1999). The impact of outsourcing and high-technology capital on wages: Estimates for the United States, 1979-1990. Quarterly Journal of Economics, 3 (114), 907-940.

Geishecker, l., Görg, H. (2008). Winners and Losers: a Micro-level Analysis of International Outsourcing and Wages. Canadian Journal of Economics, 1 (41), 243-270.

Hijzen, A., Görg, H., Hine, R.C. (2005). International outsourcing and the skill structure of labour demand in the United Kingdom. The Economic Journal, 115 (506), 860-878.

Lewine, L. (2012). Offshoring (or offshore outsourcing) and job loss among U.S. workers. CRS Report for Congress. Retrieved from: https://www.fas.org/sgp/crs/misc/RL32292.pdf (20.06.2017).

Obszary tematyczne (2017). Retrieved from: http://stat.gov.pl/obszary-tematyczne/ceny-handel/handel/uslugi-biznesowe,16,1.html (10.07.2017).

Offshoring and employment: trends and impacts (2007). Paris, OECD.

Outsourcing in Europe (2017). Retrieved from: http://www.ey.com/Publication/vwLUAssets/Outsourcing_in_Europe_2013/\$FILE/EYoutsourcing-survey.pdf (16.06.2017).

Wskaźniki (2017). Retrieved from: http://stat.gov.pl/wskazniki-makroekonomiczne (15.06.2017).

Cite this article aS:" Grześ, A. (2018). Business service industries - vendors or outsourcers? Evidence from Poland. European Journal of Service Management, 2 (26), 103-109. DOI: 10.18276/ejsm.2018.26-13. 